\title{
Variation of almond yield, biometry, $\alpha$-tocopherol levels, and antioxidant properties with nitrogen fertilization
}

\author{
Alfredo Aires $^{1}$ (D) | Maria Cristina Morais ${ }^{1}$ | David Barreales $^{2}$ | \\ Manuel Ângelo Rodrigues $^{2}$ | António Castro Ribeiro ${ }^{2}$ | Berta Gonçalves ${ }^{1,3}$ | \\ Ana Paula Silva ${ }^{1,4}$
}

\footnotetext{
${ }^{1}$ Centre for the Research and Technology for Agro-Environmental and Biological Sciences, CITAB, Universidade de Trás-osMontes e Alto Douro, Vila Real, Portugal

${ }^{2}$ Mountain Research Centre, CIMO, Escola Superior Agrária, Instituto Politécnico de Bragança, Bragança, Portugal

${ }^{3}$ Departament of Biology and

Environment, Escola das Ciências da Vida e Ambiente, Universidade de Trás-os-Montes e Alto Douro, Vila Real, Portugal

${ }^{4}$ Departament of Agronomy, Universidade de Trás-os-Montes e Alto Douro, UTAD, Vila Real, Portugal

Correspondence

Alfredo Aires, Centre for the Research and Technology for Agro-Environmental and Biological Sciences, CITAB, Universidade de Trás-os-Montes e Alto Douro, Quinta de Prados 5000-801, Vila Real, Portugal.

Email: alfredoa@utad.pt
}

\begin{abstract}
A two years' experiment (2015-2016) was set in a factorial design in which the effect of two application forms of nitrogen $(\mathrm{N}$ ) (soil and soil + foliar spray) in different doses $\left(0,25,50\right.$, and $\left.100 \mathrm{~kg} \mathrm{~N} \mathrm{ha}^{-1}\right)$ on almond (Prunus dulcis Mill. cv. "Masbovera") was evaluated. Kernel yield, biometric properties, phytochemicals, and antioxidant activities were assessed. The results showed that almond kernel yield increases with an increment in $\mathrm{N}$ rate doses $(p<0.001)$ and was positively correlated with kernel weight and thickness, and negatively with fruit weight. The levels of $\alpha$-tocopherol and total polyphenol content were higher with lower $\mathrm{N}$ doses ( 25 and $50 \mathrm{~kg} \mathrm{~N} \mathrm{ha}^{-1}$ ). The antioxidant activities were positively correlated with polyphenol content. Based on our results, excessive $\mathrm{N}$ rates over $50 \mathrm{~kg} /$ ha depreciate the levels of $\alpha$-tocopherol, total polyphenols, and antioxidant bioactivities of kernels.

Practical applications

Almond is an important nut (dry) fruit that contains high levels of $\alpha$-tocopherol, moderate levels of polyphenols, and high antioxidant activities, all responsible for their claimed health-promoting properties. Almond trees are known by their alternate behavior in which kernel yield and levels of phytochemicals and other compounds are highly variable between years. This article studies the usage of a sustainable nitrogen fertilization program toward a reduction of their alternate behavior, preserving and promoting their antioxidant properties and their levels of phytochemicals, particularly $\alpha$-tocopherol and polyphenols. Our findings may provide a useful guide for adequate nitrogen fertilization program toward a better almond kernel quality.
\end{abstract}

\section{KEYWORDS}

almonds, antioxidants, fertilizers, nitrogen, phytonutrients

\section{1 | INTRODUCTION}

Almond (Prunus dulcis Miller) is one of the most important fruit crops from Mediterranean climate areas specially in different world regions like North America, Southern and Eastern Europe, North of Africa, Middle East, Asia, and Australia (Gradziel, 2011). In the last decades, the yield of Portuguese almond orchards have been very irregular due to many factors such as irregular climatic conditions, high orchards age, low plant densities, and old pruning systems and lower knowledge about adequate crop management of the existing or new varieties onto new rootstock. Furthermore, a lack of adequate fertilization application forms has contributed to the irregular and lower yields in 
the 20 last years. Recently, a new generation of farmers is increasingly appearing who are open to following new approaches of productions and innovative techniques. Nonetheless, the majority of these innovations are related with irrigation (Cornacchia, Amodio, Colelli, \& Tortosa, 2010; García-Tejero et al., 2011; Phogat, Skewes, Mahadevan, \& Cox, 2013; Zhu, Taylor, Sommer, Wilkinson, \& Wirthensohn, 2014, 2015 ) and not with fertilization. Moreover, the research on fertilization effects on almond yield components is very limited to few recent studies (Muhammad et al., 2018; Saa et al., 2016).

Nitrogen $(\mathrm{N})$ fertilizers are widely used in crop production as a part of balanced fertilization plan, and it is commonly accepted that $\mathrm{N}$ fertilization results in increased crop growth and higher biomass yield, influencing the compositional quality of fruits (Ashraf et al., 2013; Muhammad et al., 2018; Saadati, Moallemi, Mortazavi, \& Seyyednejad, 2013), vegetables (Rajasree \& Pillai, 2012), and cereals (Ercoli, Masoni, Pampana, Mariotti, \& Arduini, 2013; Zhang et al., 2016 and Zhang et al., 2017). Nonetheless, their effects are often contradictory and excessive $\mathrm{N}$ rates might decrease $\mathrm{N}$ crop use efficiency (Rotundo \& Cipriotti, 2017) thus, decreasing their quality in several ways. Higher amount of $\mathrm{N}$ can result in reduced ascorbic acid (vitamin C) content, lower sugar content, lower acidity, and altered ratios of essential amino acids (Rajasree \& Pillai, 2012). In addition, an excessive use of $\mathrm{N}$ may increase crop production costs (Hirel, Tétu, Lea, \& Dubois, 2011) and may deteriorate soils and groundwater quality (including drinking water) by contaminating with nitrates (Gao, Howarth, Swaney, Honq, \& Guo, 2015). Therefore, in this context, we present this study, in which we evaluate the effect of different $\mathrm{N}$ rates and different $\mathrm{N}$ application forms in almond yield, biometric properties, $\alpha$-tocopherol levels, and antioxidant properties, in order to determine if it is possible to modify the quality in almonds with a feasible and a sustainable $\mathrm{N}$ fertilization regime.

\section{MATERIAL AND METHODS}

\section{1 | Experimental site}

The experiment was carried out at Alfândega da Fé region, Northeast of Portugal ( $41^{\circ} 21^{\prime} \mathrm{N} 6^{\circ} 58^{\prime} \mathrm{O}$ ), $550 \mathrm{~m}$ above sea level, from 2015 to 2016 in a 13-year-old almond (Prunus dulcis Mill. cv "Masbovera") orchard,

TAB LE 1 Meteorological data in the almonds orchards during the years 2015 and 2016, in the region of Alfândega da Fé, Northeast of Portugal $^{\mathrm{a}}$

\begin{tabular}{|c|c|c|c|c|}
\hline Year & Month & Mean temperature $\left({ }^{\circ} \mathrm{C}\right)$ & Relative Humidity (\%) & Total precipitation $(\mathrm{mm})$ \\
\hline \multirow{7}{*}{015} & February & 6.0 & 71.7 & 16.8 \\
\hline & April & 13.3 & 63.4 & 43.8 \\
\hline & May & 17.4 & 54.9 & 49.8 \\
\hline & July & 24.6 & 46.4 & 11.6 \\
\hline & August & 22.1 & 50.8 & 8.0 \\
\hline & September & 18.2 & 55.9 & 48.8 \\
\hline & October & 14.1 & 74.9 & 122.6 \\
\hline \multirow{9}{*}{2016} & February & 7.4 & 75.9 & 83.0 \\
\hline & March & 8.5 & 68.1 & 47.2 \\
\hline & April & 10.7 & 70.1 & 156.0 \\
\hline & May & 14.3 & 68.3 & 138.2 \\
\hline & June & 20.1 & 57.2 & 15.6 \\
\hline & July & 25.2 & 44.9 & 3.2 \\
\hline & August & 24.9 & 44.3 & 22.0 \\
\hline & September & 21.4 & 53.9 & 31.4 \\
\hline & October & 16.3 & 70.8 & 41.6 \\
\hline
\end{tabular}

${ }^{a}$ Data were recorded in the experimental filed through meteorological station. 
planted in an area of 9.5 ha with a plant density of 417 trees per ha. The climate data from 2015 to 2016 are recorded and summarized in Table 1.

\subsection{Fertilizer treatments}

The experiment was arranged as a factorial design with eight $\mathrm{N}$ fertilizer treatments and three replicates in two consecutive years. The experiment unit consisted of three homogeneous trees. Nitrogen was applied in two different application forms, soil and soil plus foliar sprays (Table 2). In the first regime, $\mathrm{N}$ was applied to the soil once a year (late of March of 2015 and 2016) at the rates 0 (N0), 25 (N25), 50 (N50), and 100 (N100) kg ha ${ }^{-1}$ as ammonium nitrate (27\% N). The second fertilization regime consisted of supplementing similar soil $\mathrm{N}$ treatments $\left(0,25,50\right.$, and $\left.100 \mathrm{~kg} \mathrm{~N} \mathrm{ha}^{-1}\right)$ with foliar sprays $(0.5 \%$ $\mathrm{N}$ as urea) applied three times per year during the growing season (May, July, and August of 2015 and 2016). These second groups of $N$ fertilizer treatments were, respectively, named as NOFN3, N25FN3, N50FN3, and N100FN3. Throughout the experiments, standard cultural practices (pruning and disease control) were implemented regularly.

\section{3 | Data collection}

\subsection{1 | Yield, number of fruits per tree, and fruit biometric parameters}

Trees were shaken individually using a mechanical harvester and nuts from each tree were collected and stored separately. Thirty fruits per sample were randomly selected and allowed to dry for one month. After that period, biometric parameters of fruits with shell (weight, length, width, thickness) were determined and they were hulled, cracked, and the same biometric parameters of kernels and kernel yield were determined. The kernel yield was calculated using the equation: kernel yield $(\%)=$ kernel mass $(\mathrm{g}) /$ nut weight $(\mathrm{g}) \times 100$. The samples were collected at commercial maturation in September 2015 and September 2016.

TABLE 2 Fertilizer treatments performed

\begin{tabular}{lll}
\hline Treatment designation & Nitrogen rates & Application \\
\hline N0 & $0 \mathrm{~kg} / \mathrm{ha}$ & soil \\
N25 & $25 \mathrm{~kg} / \mathrm{ha}$ & soil \\
N50 & $50 \mathrm{~kg} / \mathrm{ha}$ & soil \\
\hline N100 & $100 \mathrm{~kg} / \mathrm{ha}$ & soil \\
\hline N0FN3 & $0 \mathrm{~kg} / \mathrm{ha}+0.5 \%$ & soil + foliar sprayer \\
& nitrogen as urea & \\
\hline N25FN3 & $25 \mathrm{~kg} / \mathrm{ha}+0.5 \%$ & soil + foliar sprayer \\
& nitrogen as urea & \\
\hline N50FN3 & $50 \mathrm{~kg} / \mathrm{ha}+0.5 \%$ & soil + foliar sprayer \\
& nitrogen as urea & \\
\hline N100FN3 & $100 \mathrm{~kg} / \mathrm{ha}+0.5 \%$ & soil + foliar sprayer \\
& nitrogen as urea & \\
\hline
\end{tabular}

\subsection{2 | Total protein}

The total protein of kernels was determined by classical method of Lowry, Rosebrough, Farr, and Randall (1951), with small modifications. Briefly, $4 \mathrm{ml}$ of phosphate buffer with $\mathrm{pH} 7.0$ was added to $50 \mathrm{mg}$ of dry kernels from each sample, mixed thoroughly in a vortex, and kept at $4^{\circ} \mathrm{C}$ for $1 \mathrm{hr}$ with agitation every $20 \mathrm{~min}$. The mixtures were then centrifuged at 4,000 rpm for $15 \mathrm{~min}$ and the supernatants were collected and stored at $-20^{\circ} \mathrm{C}$ until further determinations. Simultaneously, a work solution ( $2 \mathrm{ml}$ of $1.56 \%$ copper sulfate solution in $2.37 \%$ of sodium potassium tartarate with $100 \mathrm{ml}$ of $2 \%$ sodium carbonate in $0.1 \mathrm{~N} \mathrm{NaOH}$ solution) needed to quantify the total protein content was prepared. Then, $0.4 \mathrm{ml}$ of each extract was added to $4 \mathrm{ml}$ of work solution, mixed thoroughly in a vortex, and kept at room temperature for $10 \mathrm{~min}$. Next, $0.4 \mathrm{ml}$ of FolinCiocalteu's phenol reagent $(1 \mathrm{~N})$ was added and the mixtures incubated at room temperature in the dark for $30 \mathrm{~min}$. The absorbance values at $660-\mathrm{nm}$ wavelength were then recorded in a spectrophotometer against blank (solvent used in sample extraction instead of sample) and a calibration curve with the BSA standard (bovine serum albumin-protein standard) was performed to quantify the total protein content as $\mathrm{mg} \mathrm{g}^{-1}$ dry weight (dw).

\subsection{3 | Total polyphenol content}

Total polyphenol content (TPC) of kernels was determined based on the classical colorimetric method (Singleton \& Rossi, 1965), but conducted with small modifications in a 96-well microplate (Costar 3590 , Corning, NY, USA). First, it was necessary to extract polyphenols and for that 40-mg dw kernels were weighed to 2-ml centrifuge vials and $1 \mathrm{ml}$ of methanol 70\% (methanol:water) was added. Each mixture was agitated thoroughly in a vortex and then heated at $70^{\circ} \mathrm{C}$ for $30 \mathrm{~min}$. Afterward, the mixtures were centrifuged at $11,000 \mathrm{rpm}$ at $1^{\circ} \mathrm{C}$ for $15 \mathrm{~min}$ (Eppendorf Centrifuge 5,804 R, Hamburg, Germany), the supernatants were collected and filtered with Spartan filters $(0.2 \mu \mathrm{m})$ to HPLC amber vials (Chromabond 2SVW(A) ST-CPK, Sigma-Aldrich, Tauferkichen, Germany) and the precipitate was rejected. These extracts were used to quantify TPC and in the antioxidant activity bioassays. Then, $20 \mu$ l of each extract was added to each microplate well followed by the addition of 100 $\mu \mathrm{l}$ of Folin-Ciocalteu's phenol reagent $\left(1: 10\right.$ in $\mathrm{dd} \mathrm{H}_{2} \mathrm{O}$ ) and $80 \mu \mathrm{l}$ of $7.5 \% \mathrm{Na}_{2} \mathrm{CO}_{3}$. Then, the microplates were heated at $45^{\circ} \mathrm{C}$ for $15 \mathrm{~min}$ and the absorbance values were measured at $765-\mathrm{nm}$ wavelength in a microplate reader (Multiskan ${ }^{\mathrm{TM}} \mathrm{GO}$ Microplate Spectrophotometer, Thermo Scientific, Vantaa, Finland), against blank (all reagents except sample). A calibration curve with a commercial standard of gallic acid at different concentrations $\left(\mathrm{mg} \mathrm{ml}^{-1}\right)$ was performed and the results were expressed as $\mathrm{mg}$ gallic acid equivalent (GAE) $\mathrm{g}^{-1} \mathrm{dw}$.

\subsection{4 | $\alpha$-Tocopherol}

The levels of $\alpha$-tocopherol in the kernel samples were determined by high-performance liquid chromatography (HPLC), according to 
the adaptation of the method used by Gueguen, Herbeth, Siest, and Leroy (2002) with several modifications. Ten milliliters of a solvent mixture, methanol:dichcorlometane (1:1), were added to $1 \mathrm{~g}$ of $\mathrm{dw}$ of kernels, mixed thoroughly in a vortex, and sonicated for $20 \mathrm{~min}$. Then, the mixtures were centrifuged at $4,000 \mathrm{rpm}$ and room temperature for $10 \mathrm{~min}$. The supernatants were collected, filtered (PTFE $0.2 \mu \mathrm{m}, \varnothing 13 \mathrm{~mm}$ (Teknokroma, Spain) and stored in HPLC amber vials (Chromabond 2-SVW(A) ST-CPK, Sigma-Aldrich, Tauferkichen, Germany) and immediately injected in HPLC-DAD-UV/Vis system to avoid any substantial losses of vitamin $\mathrm{E}$ by degradation. The HPLC system was set with the following parameters: a C18 column

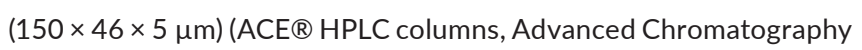
Technologies, Ltd., Aberdeen, Scotland); an eluent of absolute methanol with $0.1 \%$ of trifluoroacetic acid (TFA); and an isocratic gradient with a flow of $1 \mathrm{ml} \mathrm{min}^{-1}$ in a run length of $15 \mathrm{~min}$. The detection was performed at 296-nm wavelength. The identification and quantification of $\alpha$-tocopherol was made using the retention time (7.06 min.) of the peaks obtained in the chromatograms, UV spectra of detected compound compared with external commercial standard of $\alpha$-tocopherol (Sigma-Aldrich, Tauferkichen, Germany), and standard curve for external standardization. The results are expressed as $\mathrm{mg}$ $\mathrm{g}^{-1}$ of $\alpha$-tocopherol.

\subsection{5 | Antioxidant activity}

\section{Anti-lipid peroxidation bioassay}

The modified thiobarbituric acid reactive species (TBARS) assay was used to measure the lipid peroxide formed using egg yolk homogenates as lipid-rich media, described previously by Adithya, Lakshmi, Christabel, and Sasikumar (2013) in a 96-well microplate (Costar 3590, Corning, NY, USA). Briefly, $20 \mu \mathrm{l}$ of substrate (homogenate of egg yolk at $10 \%$ in $0.1 \mathrm{M}$ phosphate buffer, $\mathrm{pH}$ 7.4) and $5 \mu \mathrm{l}$ of $\mathrm{FeSO}_{4}(1 \mathrm{mM}$ in water) were added, followed by addition of $20 \mu$ l of extract (same extracts used to quantify TPC) and $65 \mu \mathrm{l}$ of $\mathrm{ddH}_{2} \mathrm{O}$. Then, the microplates were incubated for $15 \mathrm{~min}$ at $37^{\circ} \mathrm{C}$. After, $50 \mu \mathrm{l}$ of trichloroacetic acid (50\% in water) and $100 \mu \mathrm{l}$ of tiobarbituric acid (TBA) (0.8\% in phosphate buffer) were added sequentially, and the microplates were incubated again at $95^{\circ} \mathrm{C}$ for 15 min until a pink color appears. Then, the absorbance values (Abs) were recorded at $532 \mathrm{~nm}$ in a microplate reader (Multiskan ${ }^{\text {TM }} \mathrm{GO}$ Microplate Spectrophotometer, Thermo Scientific, Vantaa, Finland). Simultaneously, a complete oxidized extract (egg yolk $+\mathrm{FeSO}_{4}$, without extract) was used as control. The results were expressed as \% lipid peroxidation inhibition using the following formula: (\%) lipid peroxidation inhibition $=\left(\mathrm{Abs}_{\text {control }}-\mathrm{Abs}_{\text {sample }} / \mathrm{Abs}_{\text {control }}\right) \times 100$.

\section{Ferric reduction capacity}

The ferric-reducing capacity of almond extracts was determined by the ferric reduction capacity (FRAP) method described by Stratil, Klejdus, and Kubán (2006) with several modifications. In the dark, FRAP reagent was made with $300 \mathrm{mmol} \mathrm{L}^{-1}$ acetate buffer ( $\mathrm{pH} 3.6$ ), $10 \mathrm{mmol}$ 2,4, 6-tripyridyl-S-triazine 10 (TPTZ) (Sigma-Aldrich, Tauferkichen, Germany) in a $40 \mathrm{mmol} \mathrm{L}^{-1} \mathrm{HCl}$ (Sigma-Aldrich,
Tauferkichen, Germany) solution and $20 \mathrm{mmol} \mathrm{L}^{-1} \quad \mathrm{FeCl}_{3} 6 \mathrm{H}_{2} \mathrm{O}$ (Sigma-Aldrich, Tauferkichen, Germany). Then, $25 \mu \mathrm{L}$ of each extract (same extracts used to quantify TPC) or standard solutions was combined with $275 \mu \mathrm{L}$ of FRAP reagent. After incubating for 5 min in the dark and room temperature, the absorbance values were recorded at $593 \mathrm{~nm}$ in microplate reader (Multiskan ${ }^{\text {TM }} \mathrm{GO}$ Microplate Spectrophotometer, Thermo Scientific, Vantaa, Finland) against blank. Simultaneously, a calibration curve with $\mathrm{FeSO}_{4}$ was produced in order to express the results as equivalent to $\mu \mathrm{M}$ FeSO4.

\section{DPPH free radical scavenging activity}

The free radical scavenging activity of almond extracts were determined by the 2,2-diphenyl-1-picryl-hydrazyl (DPPH) assay (Siddhraju $\&$ Becker, 2003) conducted in a 96-well microplate (Costar 3590, Corning, NY, USA). Briefly, $285 \mu$ l of freshly DPPH (Sigma-Aldrich, Tauferkichen, Germany) solution (4 mg of DPPH in $100 \mathrm{ml}$ of $95 \%$ of ethanol) was added to each microplate well, followed by the addition of $15 \mu$ l of extract (same extracts used to quantify TPC). A blank sample (all reagents and extraction solvent instead of sample) added to one well. Then, the microplates were incubated in the dark, at room temperature for $30 \mathrm{~min}$. After this period, the absorbance values (Abs) were recorded at 517-nm wavelength in a microplate reader (Multiskan ${ }^{\text {TM }}$ GO Microplate Spectrophotometer, Thermo Scientific, Vantaa, Finland). The results were expressed as $\%$ free $\mathrm{DPPH}$ radical scavenging capacity using the following formula: \% $\mathrm{DPPH}_{\text {scavenging capacity }}=\left(\mathrm{Abs}_{\text {blank }}-\mathrm{Abs}_{\text {sample }} / \mathrm{Abs}_{\text {blank }}\right) \times 100$.

\section{4 | Statistical analysis}

All determinations were done in triplicate and the results were analyzed using a two-way ANOVA in factorial arrangement followed by Tukey test, based on confidence level equal to or higher than $95 \%$ $(p<0.05)$. The results were expressed as mean values \pm standard deviation (SD) of three replicates. The software SPSS V.17 (SPSS-IBM, Orchard Road-Armonk, New York, NY, USA) was used to carry out these analyses. A linear regression was determined between kernel yield and all biometric properties of almond shells and kernels. In addition, a Pearson's correlation was performed between the chemical parameters and antioxidant activity results in order to establish the influence between them.

\section{3 | RESULTS AND DISCUSSION}

Table 1 summarizes the parameters of temperature, precipitation, and humidity for 2015 and 2016. The average temperatures were very similar between both years but in the second year the precipitation and humidity was higher particularly in the first 5 months of the year.

Table 2 presents the treatments performed and Table 3 presents the average levels for each biometric property (weight, length, width, and thickness) of almond shells and kernels. Figure1 presents the variation of kernel yield between years and treatments. 


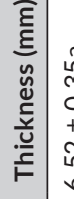

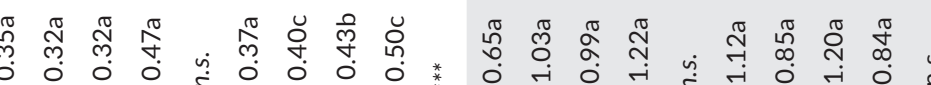

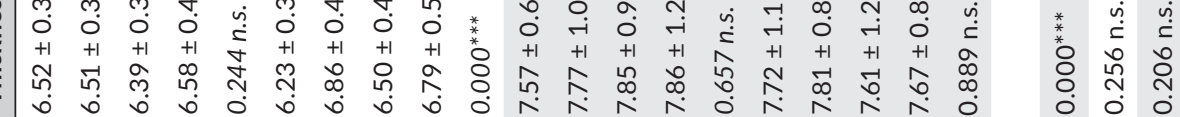

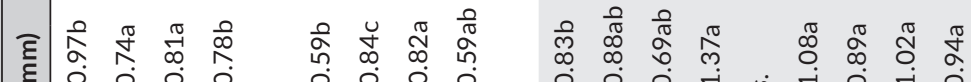

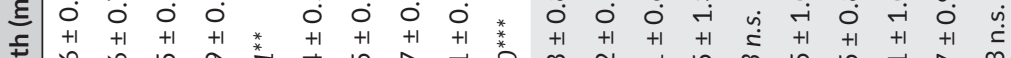

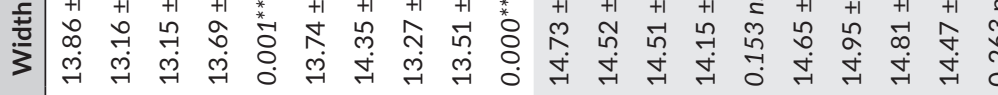

हี

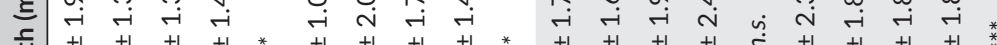

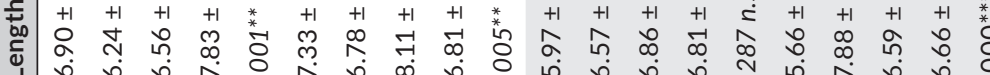

ฮ

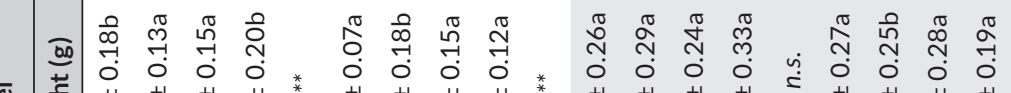

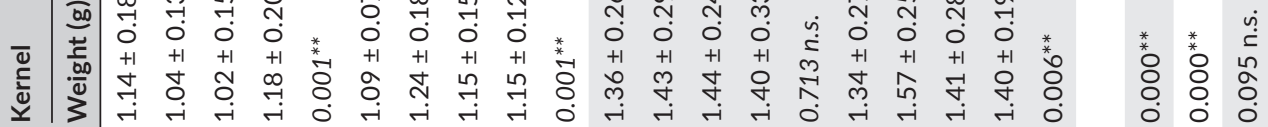

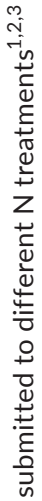

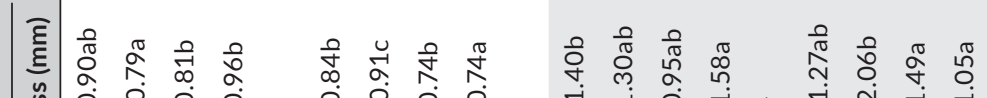

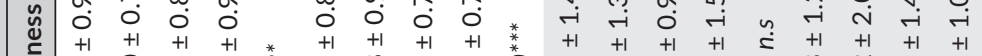

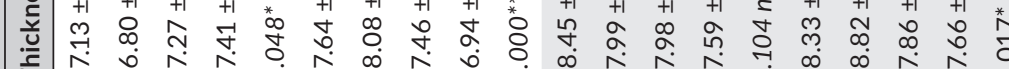

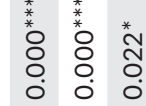

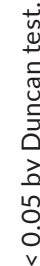

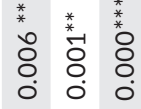

$F$

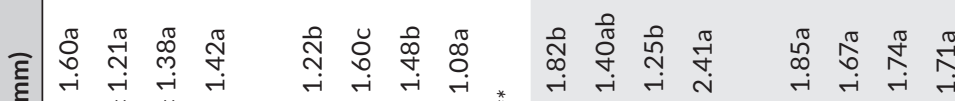

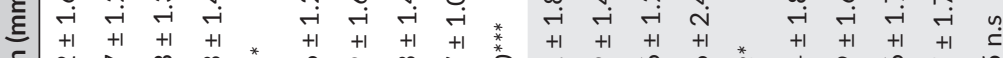

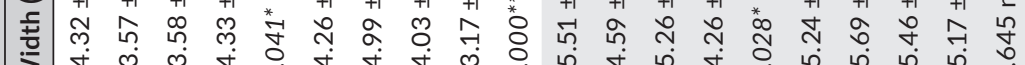

उँ

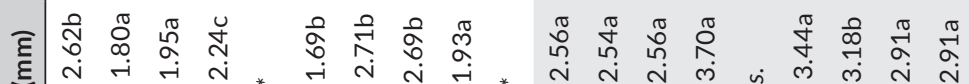

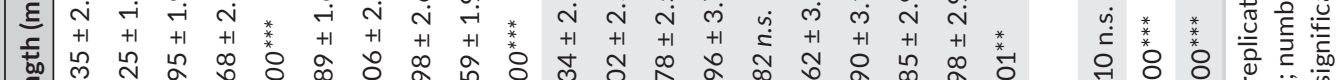

ब

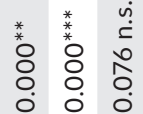

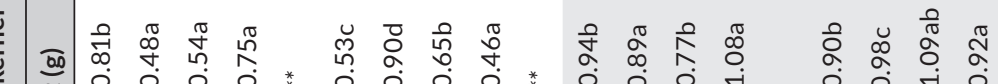

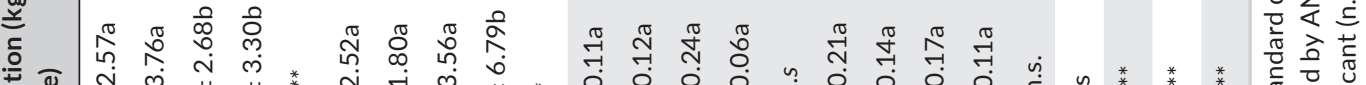

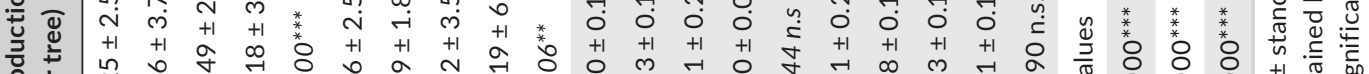

范 $m m^{m} \sum_{z}^{m}$ 


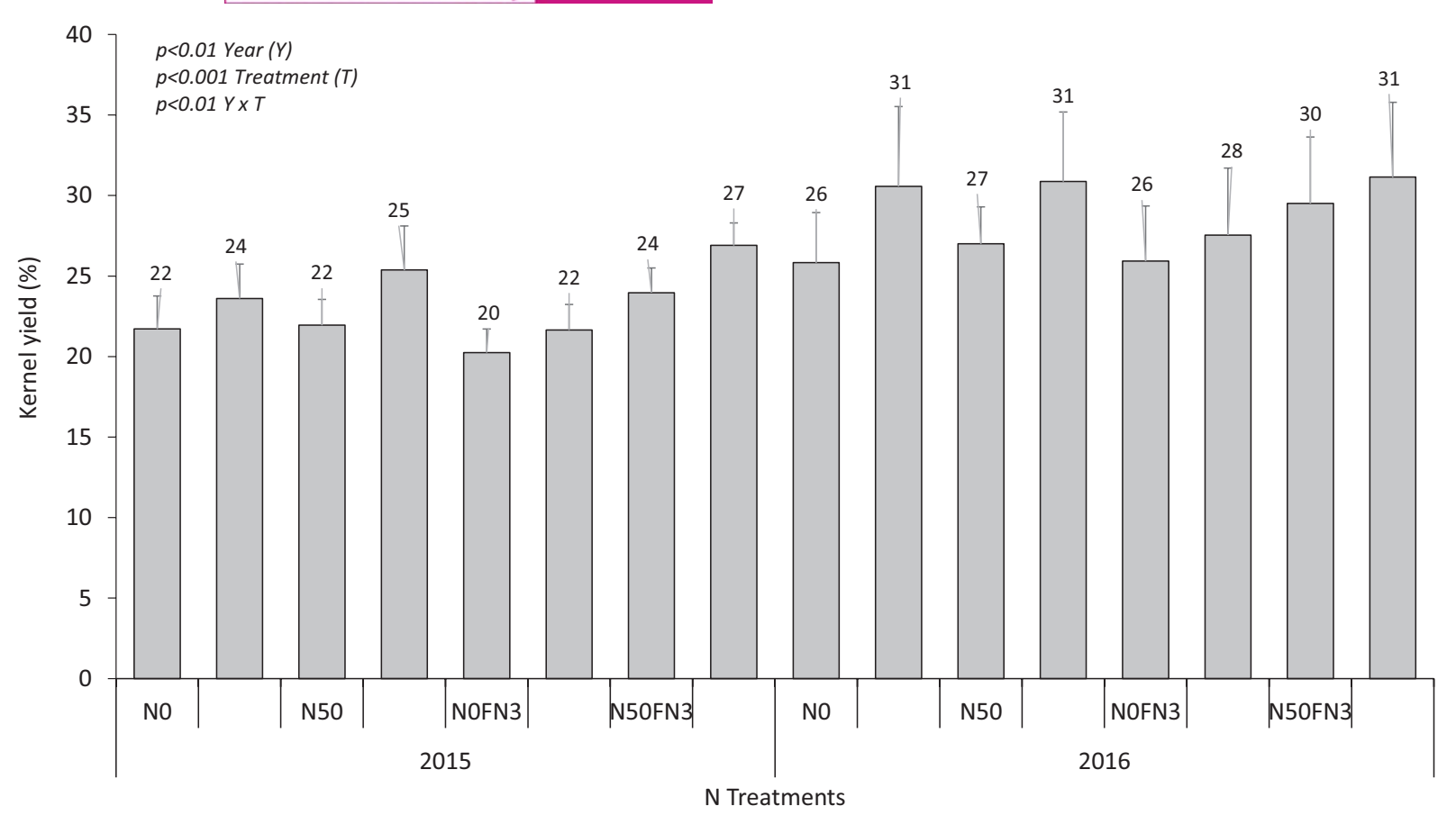

FIGURE 1 Kernel yield expressed as percentage \pm standard deviation (SD), throughout 2015-2016

Figure 2 wpresents the influence of each almond biometric property on kernel yield by a linear regression calculation with the respective equations. In general, treatments and year influenced significantly the shells + kernels width and thickness and kernels' weight, and width $(p<0.001)$. The length of kernels was less influenced by both factors $(p<0.01)$ and thickness of kernels was only significantly affected by treatments $(p<0.001)$. Comparatively, the kernel yield was higher in 2016 than in 2015, particularly when higher $\mathrm{N}$ rates were applied either to the soil (N100, $100 \mathrm{~kg} \mathrm{ha}^{-1}$ ) or in combination with $\mathrm{N}$ foliar sprayers (N100FN $3,100 \mathrm{~kg} /$ ha) (Figure 1). The increments in the kernel yields were positively correlated with kernel weight and thickness, and negatively with fruit weight (shell + kernel) (Figure 2).

The average levels of $\alpha$-tocopherol, total soluble proteins, and TPC, and the antioxidant activity of kernels are presented in Table 4 and Figure 3, respectively. In general, the average values of tocopherols, total soluble proteins, and TPC were similar in both years of experiment, while the antioxidant activities followed an opposite trend depending on the method used in their determination (Figure 3). However, the antioxidant activity seems to be related to the variation of TPC content as shown by the Pearson correlation results presented in Table 5. The levels of $\alpha$-tocopherol and TPC were higher when lower N doses (N25, N50, N25FN3) were applied, particularly in the second year of experiment, which was followed by the antioxidant activity results, except for FRAP method (Figure 3). While, the amount of total soluble proteins were higher when the highest N doses (N100 and N100FN3) were applied in both years of experiment.

The quality attributes in almonds (shell + kernels) like in other fruit species are highly dependent on cultural practices and environmental conditions. According to the climate data recorded in the almond orchard (Table 1), the precipitation was very limited in the first 5 months of 2015, while in 2016, excess of precipitation and humidity was observed in a similar period when blooming, flowering, and pollination occurred, which might have a negative impact on fruit setting and therefore less yield occurred (Table 3). Although the constrain effect of precipitation and humidity it was possible to observe that biometric properties of almonds shells + kernels and kernels increased in the second year of production, maybe due to the positive action of nitrogen fertilizations (Table 3). Similar trend was observed for compositional attributes (Table 4). In fact, after $\mathrm{N}$ fertilizations, particularly in the second year of experiment, kernel yields were higher when high $\mathrm{N}$ rates were applied either to the soil (N100, $100 \mathrm{~kg} \mathrm{ha}^{-1}$ ) or in combination with $\mathrm{N}$ foliar sprayers (N100FN ${ }_{3}$, $100 \mathrm{~kg} / \mathrm{ha}$ to the soil plus three doses of $0.5 \% \mathrm{~N}$ foliar) (Table 3). This increment was positively correlated with kernel weight, width, and thickness, and negatively with fruit weight (shell + kernel) (Figure 2). These results are in agreement with previous studies of Raese (1997), Saenz, DeJong, and Weinbaum (1997), Gray and Garrett (1998) and Gunes, Okay, Koksal, and Koroglu (2010) which recorded high yields with high rates of $\mathrm{N}$, in different types of tree crops.

A different trend was observed for $\alpha$-tocopherol, total proteins, and TPC of kernels (Table 3). The levels of $\alpha$-tocopherol, total proteins, and TPC were higher when moderate $\mathrm{N}$ rates (N25, N50, N25FN3) were applied. In addition, the increment was higher in the second year of experiment. This year-to-year variation could be due to the cumulative effect of $\mathrm{N}$ fertilization. Pérez-Zamora and Cigales-Rivero (2001) in cantaloupe melon found that increasing $\mathrm{N}$ fertilization produces an increase in the fruit quality attributes up to a maximum value, due to a cumulative effect of N. However, the same author reported that if the supply continues increasing, 

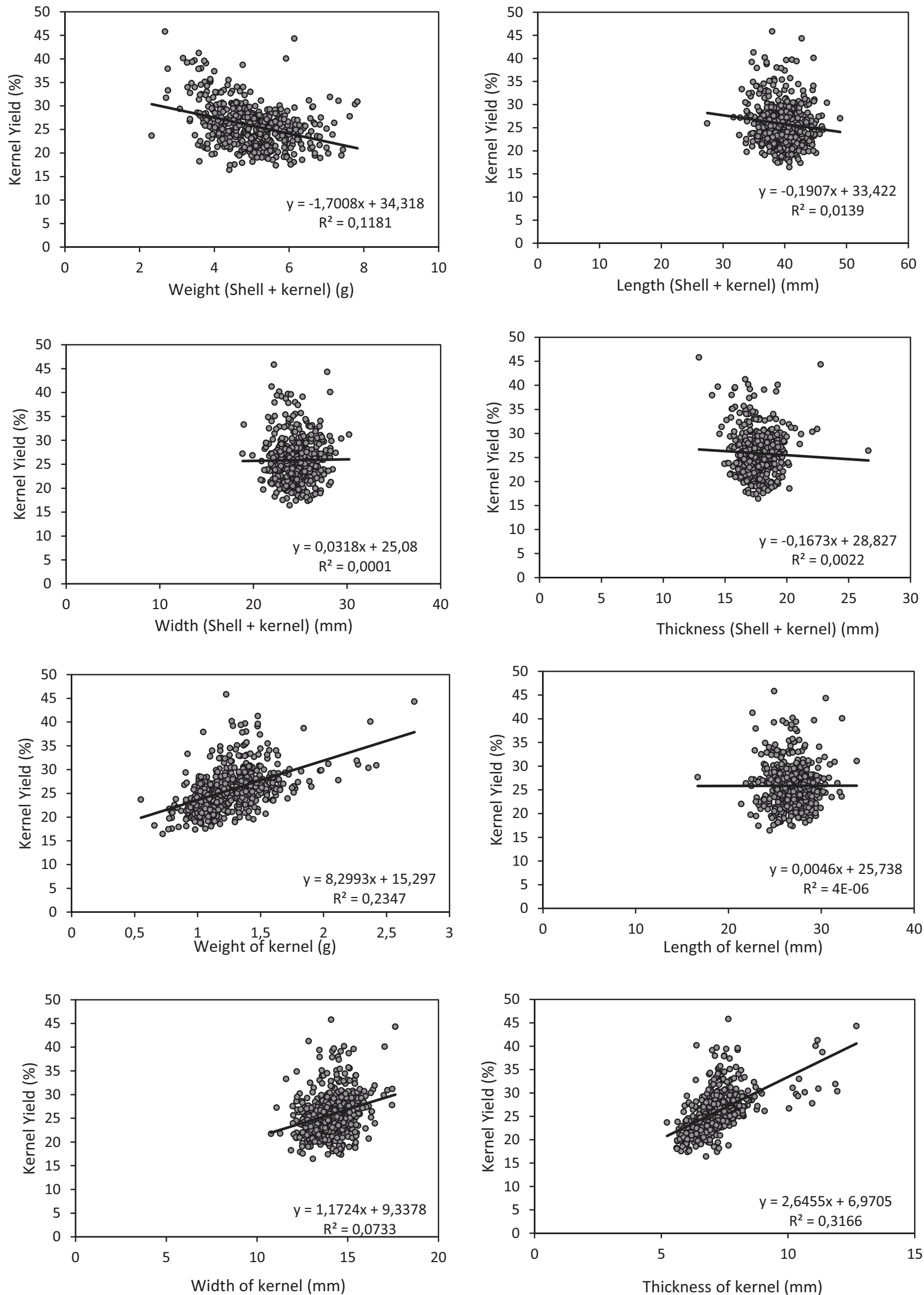

FIGURE 2 Relation between kernel yield and the different biometric parameters measured 
TAB LE 4 Average value of chemical properties of almond nuts, submitted to different $\mathrm{N}$ treatments $\mathrm{s}^{\mathrm{a}, \mathrm{b}, \mathrm{c}}$

\begin{tabular}{|c|c|c|c|c|}
\hline Year & Treatment & $\alpha$-Tocopherol (mg g ${ }^{-1}$ ) & Total soluble protein $\left(\mathrm{mg} \mathrm{g}^{-1}\right)$ & $\begin{array}{l}\text { Total polyphenols } \\
\left(\mathrm{mg} \mathrm{g}^{-1}\right)\end{array}$ \\
\hline \multirow[t]{8}{*}{2015} & NO & $0.155 \pm 0.01 b$ & $239,61 \pm 29,64 a$ & $1,31 \pm 0,20 b$ \\
\hline & N50 & $0.125 \pm 0.02 a$ & $254,67 \pm 10,54 a b$ & $0,96 \pm 0,27 a b$ \\
\hline & N100 & $0.130 \pm 0.00 a$ & $273,76 \pm 6,14 b$ & $0,87 \pm 0,22 a$ \\
\hline & NOFN3 & $0.123 \pm 0.00 \mathrm{ab}$ & $223,95 \pm 4,08 a$ & $1,21 \pm 0,09 a$ \\
\hline & N25FN3 & $0.133 \pm 0.02 b$ & $232,87 \pm 11,50 a$ & $1,25 \pm 0,27 a$ \\
\hline & N50FN3 & $0.129 \pm 0.01 \mathrm{ab}$ & $232,25 \pm 6,88 a$ & $1,27 \pm 0,44 a$ \\
\hline & N100FN3 & $0.109 \pm 0.01 a$ & $242,30 \pm 25,28 a$ & $0,93 \pm 0,02 a$ \\
\hline & $p$ value & 0.078 n.s. & 0.524 n.s. & 0.398 n.s. \\
\hline \multirow{7}{*}{2016} & N100 & $0.130 \pm 0.02 a$ & $237,48 \pm 86,41 a$ & $1,45 \pm 0,65 a$ \\
\hline & $p$ value & 0.698 n.s. & 0.413 n.s. & 0.628 n.s. \\
\hline & NOFN3 & $0.144 \pm 0.01 a$ & $203,24 \pm 44,26 a$ & $1,39 \pm 0,50 a$ \\
\hline & N25FN3 & $0.143 \pm 0.02 a$ & $268,29 \pm 20,38 a$ & $1,17 \pm 0,76 a$ \\
\hline & N50FN3 & $0.142 \pm 0.01 a$ & $274,81 \pm 50,63 a$ & $0,88 \pm 0,17 a$ \\
\hline & N100FN3 & $0.148 \pm 0.00 a$ & $249,55 \pm 64,86 a$ & $1,23 \pm 0,17 a$ \\
\hline & $p$ value & 0.559 n.s. & 0.375 n.s. & 0.633 n.s. \\
\hline \multicolumn{2}{|c|}{ Source of Variance } & $p$ values & & \\
\hline
\end{tabular}

${ }^{\text {a } V a l u e s ~ e x p r e s s e d ~ a s ~ m e a n ~} \pm$ standard deviation (SD) of three replicates.

${ }^{b}$ Probability test values obtained by ANOVA variance analysis; number with different letters in same column are significantly different from another at $p<0.05$ by Duncan test.

'The symbols means: not significant (n.s.); significant $\left({ }^{*}\right)$, very significant $\left({ }^{* *}\right)$; highly significant $\left({ }^{* * *}\right)$.

the amount and quality of production might be affected negatively, which is in agreement with our findings, because at higher $\mathrm{N}$ doses (N50, N100, and N50FN3, N100FN3), the levels of tocopherol, total proteins, and TPC decreased. Therefore, we can state that extreme $\mathrm{N}$ levels (to low or to high) had a depressive effect on biometric and compositional attributes of almonds. These results have also consequences in the antioxidant properties of kernels (Figure 3). The variation found for antioxidant properties of kernels (Figure 3) measured by lipid peroxidation, FRAP, and DPPH bioassays, was only affected significantly affected by TPC (Table 5). The difference in trends observed for the twee methods in particularly for FRAP compared to DPPH and Lipid peroxidation assays could reside in the presence of other compounds not determined in current work. Surprisingly, the levels of $\alpha$-tocopherol in samples had no significant effect $(p>0.05$ ) on their antioxidant activity. $\alpha$-Tocopherol has been reported as having important antioxidant activity (Ryo, 1997); however, in this work that seems not the case, maybe because is in lower levels or their influence might be supplanted by TPC.
Another important finding of this study resides in the fact that $\mathrm{N}$ applied only to the soil seems to be enough to preserve and promote the quality of almond kernels. In both years of experiment, the average content of $\alpha$-tocopherol, total proteins and TPC were always higher in trees submitted to a unique $\mathrm{N}$ dose (Table 4). This result suggests that single application of $\mathrm{N}$ into the soil at lower $\mathrm{N}$ rates is enough to promote, improve, or preserve the almond compositional quality, which is in agreement with the previous cited authors who found that excessive $\mathrm{N}$ has a depreciative effect in produces quality.

Based on the results of this study, we can state that extreme $\mathrm{N}$ levels (to low or to high) might have a positive effect on almond kernel yield but have a depressive effect on their compositional quality and antioxidant properties. The lack of significant tree response to high $\mathrm{N}$ rate applications may reflect the use of stored nutrients in perennial tree parts but not for the fruit composition as was observed by Ding et al. (2017) for dwarf apple trees. Liu, Sung, Chen, and Lai (2014), Miceli and Miceli (2014) and Saa et al. (2016), found 

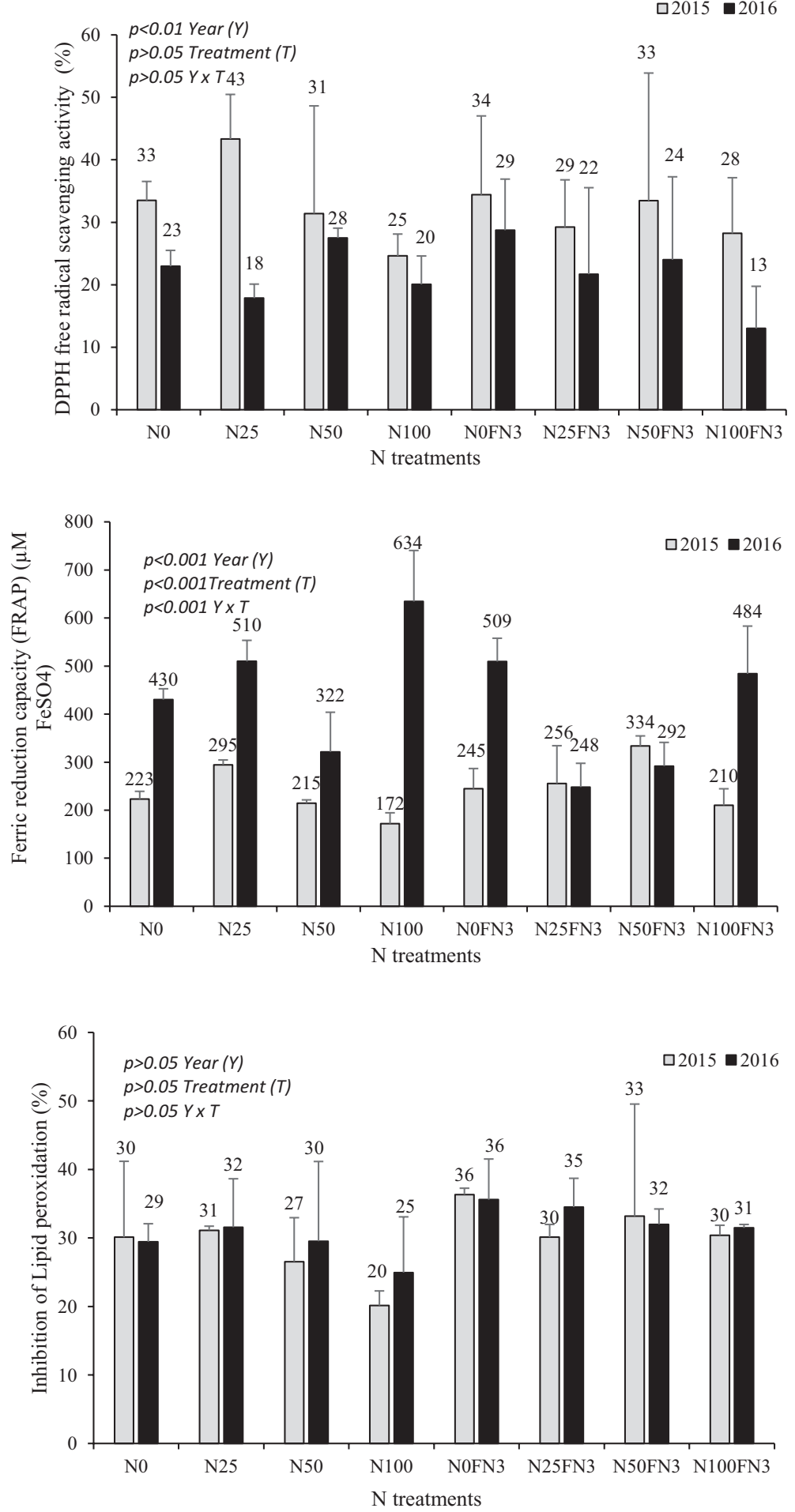

FIGURE 3 Mean \pm standard deviation $(S D)$ values of antioxidant activity of almond kernels, measured by three different methods

that high rates of $\mathrm{N}$ decrease $\mathrm{N}$ crop use efficiency, cause a loss of minerals and bioactive compounds of edible part of plants, and an excessive accumulation of undesirable nitrates in plants, soil, and ground water. Therefore, lower $\mathrm{N}$ rates of $\mathrm{N}$ increase and preserve the quality of almonds without affecting the environment. Our results suggest that for almond and from quality point of view, there are no significant benefit of increasing $\mathrm{N}$ over $50 \mathrm{~kg} / \mathrm{ha}$.
To conclude, increasing $\mathrm{N}$ fertilization rates increases kernel yield through an increment of kernel weight and thickness, but an excessive $\mathrm{N}$ application can depreciate the nutritional quality and bioactive properties of almonds. Therefore, a regime with $\mathrm{N}$ rates of $25 \mathrm{~kg} / \mathrm{ha}$ and $50 \mathrm{~kg} / \mathrm{ha}$ applied only to the soil is enough to promote and preserve the nutritional quality and bioactive properties of almonds and probably reduce their alternate behavior. 
TAB LE 5 Pearson's correlation coefficients ${ }^{1,2,3}$

\begin{tabular}{|c|c|c|c|c|c|c|}
\hline & $\begin{array}{l}\alpha- \\
\text { Tocopherol }\end{array}$ & $\begin{array}{l}\text { Total } \\
\text { soluble } \\
\text { protein }\end{array}$ & Total polyphenols & $\begin{array}{l}\text { Inhibition of Lipid } \\
\text { peroxidation }\end{array}$ & $\begin{array}{l}\text { Ferric reduction } \\
\text { capacity }\end{array}$ & $\begin{array}{l}\text { DPPH free radical } \\
\text { scavenging activity }\end{array}$ \\
\hline$\alpha$-Tocopherol & 1 & $\begin{array}{l}0.170 \\
(0.254)\end{array}$ & $0.133(0.372)$ & $0.119(0.424)$ & $0.193(0.193)$ & $0.119(0.427)$ \\
\hline Total soluble protein & & 1 & $-0.291(0.047)^{*}$ & $-0.015(0.920)$ & $-0.015(0.920)$ & $-0.063(0.676)$ \\
\hline Total polyphenols & & & 1 & $0.352(0.015)^{*}$ & $0.406(0.005)^{* *}$ & $0.181(0.223)$ \\
\hline $\begin{array}{l}\text { Inhibition of Lipid } \\
\text { peroxidation }\end{array}$ & & & & 1 & $0.080(0.593)$ & $0.282(0.055)$ \\
\hline $\begin{array}{l}\text { Ferric reduction } \\
\text { capacity }\end{array}$ & & & & & 1 & -0.209 (0.159) \\
\hline $\begin{array}{l}\text { DPPH free radical } \\
\text { scavenging activity }\end{array}$ & & & & & & 1 \\
\hline
\end{tabular}

The next steps of research is to understand how nitrogen affects the biosynthetic mechanisms of $\alpha$-tocopherol and other antioxidant compounds as well as the levels of antioxidant enzymes and pigments, which may be critical to the carbohydrates balance of plant and physiological behavior of almond trees, particularly for the formation of leafs, spurs, flowers, and fruits. This information will be important to understand how antioxidant compounds can be maximized.

\section{ACKNOWLEDGMENTS}

The authorsacknowledge the financial support of INTERACT project"Integrative Research in Environment, Agro-Chains and Technology," no. NORTE-01-0145-FEDER-000017, in its line of research entitled ISAC, co-financed by the European Regional Development Fund (ERDF) through NORTE 2020 (North Regional Operational Program 2014/2020). The author Alfredo Aires acknowledges the financial support of BPD/UTAD/INTERACT/ISAC/189/2016 scholarship, under the same project. The authors also acknowledge the support of European Investment Funds by FEDER/COMPETE/POCIOperational Competitiveness and Internationalization Programme, under Project POCI-01-0145-FEDER-006958 and National Funds by FCT-Portuguese Foundation for Science and Technology, under the project UID/AGR/04033/2013.

The authors also acknowledge the financial support of European Agricultural and Rural development fund (FEADER) under the Project "Estratégias Integradas para o aumento da produtividade da amendoeira em Trás-os-Montes $n^{\circ}$ 54611, and by Portuguese State through the "Medida 4.1. Cooperação para a Inovação do programa PRODER - Programa de Desenvolvimento Rural."

\section{CONFLICT OF INTEREST}

Authors declared that they have no conflict of interest.

\section{ORCID}

Alfredo Aires iD http://orcid.org/0000-0001-6291-8413

\section{REFERENCES}

Adithya, E. S., Lakshmi, M. S., Christabel, P. H., \& Sasikumar, J. M. (2013). In vitro antioxidant, anti-lipd peroxidation activities and HPLC analysis of methanol extracts from bark and stem of Mahonia leschenaultia takeda. Asian Journal of Plant Science and Research, 3(2), 116-126.

Ashraf, N., Ashraf, M., Hassan, G., Rehman, M. U., Dar, N. A., Khan, I. M., ... Banday, S. A. (2013). Effect of foliar application of nutrients and biostimulant on nut quality and leaf nutrient status of pecan nut cv. "Western Schley". African Journal of Agricultural Research, 8(6), 559-563.

Cornacchia, R., Amodio, M. L., Colelli, G., \& Tortosa, P. A. N. (2010). Effect of irrigation water reduction strategies on quality at harvest and during storage of in-shell almonds. Acta Horticulturae, 877, 251259. https://doi.org/10.17660/ActaHortic.2010.877.28

Ding, N., Chen, Q., Zhu, Z., Peng, L., Ge, S., \& Jiang, Y. (2017). Effects of crop load on distribution and utilization of $13 \mathrm{C}$ and $15 \mathrm{~N}$ and fruit quality for dwarf apple trees. Scientific Reports, 7(1), 14172. https:// doi.org/10.1038/s41598-017-14509-3

Ercoli, L., Masoni, A., Pampana, S., Mariotti, M., \& Arduini, I. (2013). As durum wheat productivity is affected by nitrogen fertilisation management in Central Italy. European Journal of Agronomy, 44, 38-45. https://doi.org/10.1016/j.eja.2012.08.005

Gao, W., Howarth, R. W., Swaney, D. P., Honq, B., \& Guo, H. C. (2015). Enhanced N input to Lake Dianchi Basin from 1980 to 2010: Drivers and consequences. Science of the Total Environment, 505, 376-384. https://doi.org/10.1016/j.scitotenv.2014.10.016

García-Tejero, I. F., Durán-Zuazo, V. H., Vélez, L. M., Hernández, A., Salguero, A., \& Muriel-Fernández, J. L. (2011). Improving almond productivityunder deficitirrigation in semiaridzones. The OpenAgriculture Journal, 5, 56-62. https://doi.org/10.2174/1874331501105010056

Gradziel, T. M. (2011). Origin and dissemination of almond. Horticultural Reviews, 38, 23-81.

Gray, D., \& Garrett, H. E. G. (1998). Nitrogen fertilization and aspects of fruit yield in a Missouri black walnut alley cropping practice. Agroforestry Systems, 44(2), 333-344.

Gueguen, S., Herbeth, B., Siest, G., \& Leroy, P. (2002). An isocratic liquid chromatographic method with diode-array detection for the simultaneous determination of $\mu$-tocopherol, retinol, and five carotenoids in human serum. Journal of Chromatographic Science, 40(2), 69-76.

Gunes, N. T., Okay, Y., Koksal, A. I., \& Koroglu, M. (2010). The effect of nitrogen and phosphorus fertilization on yield, some fruit characteristics, hormone concentrations, and alternate bearing in pistachio. Turkish Journal of Agriculture and Forestry, 34(1), 33-43. 
Hirel, B., Tétu, T., Lea, P. J., \& Dubois, F. (2011). Improving nitrogen use efficiency in crops for sustainable agriculture. Sustainability, 2011(3), 1452-1485. https://doi.org/10.3390/su3091452

Liu, C.-W., Sung, Y., Chen, B.-C., \& Lai, H.-Y. (2014). Effects of nitrogen fertilizers on the growth and nitrate content of lettuce (Lactuca sativa L.). International Journal of Environmental Research and Public Health, 11(4), 4427-4440. https://doi.org/10.3390/ijerph110404427

Lowry, O. H., Rosebrough, N. J., Farr, A. L., \& Randall, R. J. (1951). Protein measurement with the Folin Phenol reagent. Journal of Biological Chemistry, 193(1), 265-275.

Miceli, A., \& Miceli, C. (2014). Effect of nitrogen fertilization on the quality of Swiss chard at harvest and during storage as minimally processed produce. Journal of Food Quality, 37(2), 125-134. https://doi. org/10.1111/jfq.12073

Muhammad, S., Sanden, B. L., Saa, S., Lampinen, B. D., Smart, D. R., Shackel, K. A., ... Brown, P. H. (2018). Optimization of nitrogen and potassium nutrition to improve yield and yield parameters of irrigated almond (Prunus dulcis (Mill.) D. A. webb). Scientia Horticulturae, 228, 204-212. https://doi.org/10.1016/j.scienta.2017.10.024

Pérez-Zamora, O., \& Cigales-Rivero, M. (2001). Soil moisture tension and nitrogen fertilization on cantaloupe melon. Agrociencia, 35, 479-488.

Phogat, V., Skewes, M. A., Mahadevan, M., \& Cox, J. W. (2013). Evaluation of soil plant system response to pulsed drip irrigation of an almond tree under sustained stress conditions. Agricultural Water Management, 118, 1-11. https://doi.org/10.1016/j.agwat.2012.11.015

Raese, J. T. (1997). Cold tolerance, yield, and fruit quality of 'd'Anjou' pears influenced by nitrogen fertilizer rates and time of application. Journal of Plant Nutrition, 20(7-8), 1007-1025. https://doi. org/10.1080/01904169709365313

Rajasree, G., \& Pillai, G. R. (2012). Effect of nitrogen nutrition on fruit quality and shelf life of curcubitaceous vegetable bitter gourd. Journal of Plant Nutrition, 35(8), 1139-1153.

Rotundo, J. L., \& Cipriotti, P. A. (2017). Biological limits on nitrogen use for plant photosynthesis: A quantitative revision comparing cultivated and wild species. New Phytologist, 214, 120-131. https://doi. org/10.1111/nph.14363

Ryo, Y. (1997). Vitamin E: Mechanism of its antioxidant activity. Food Science and Technology International, 3(4), 301-309.

Saa, S., Peach-Fine, E., Brown, P. H., Michailides, T. J., Castro, S., Bostock, R., \& Laca, E. (2016). Nitrogen increases hull rot and interferes with the hull split phenology in almond (Prunus dulcis). Scientia Horticulturae, 199, 41-48. https://doi.org/10.1016/j.scienta.2015.12.027

Saadati, S., Moallemi, N., Mortazavi, S. M. H., \& Seyyednejad, S. M. (2013). Effects of zinc and boron foliar application on soluble carbohydrate and oil contents of three olive cultivars during fruit ripening. Scientia Horticulturae, 164, 30-34. https://doi.org/10.1016/j. scienta.2013.08.033

Saenz, J. L., DeJong, T. M., \& Weinbaum, S. A. (1997). Nitrogen stimulated increases in peach yields are associated with extended fruit development period and increased fruit sink capacity. Journal of the American Society for Horticultural Science, 122(6), 772-777.

Siddhraju, P., \& Becker, K. (2003). Antioxidant properties of various solvents extracts of total phenolic constituents from three different agroclimatic origins of drumstick tree (Moringa oleifera Lam) leaves. Journal of Agricultural and Food Chemistry, 51(8), 2144-2155.

Singleton, V. L., \& Rossi, J. A. (1965). Colorimetry of total phenolics with phosphomolybdic-phosphotungstic acid reagents. American Journal of Enology and Viticulture, 16, 144-158.

Stratil, P., Klejdus, B., \& Kubán, V. (2006). Determination of total content of phenolic compounds and their antioxidant activity in vegetablesevaluation of spectrophotometric methods. Journal of Agricultural and Food Chemistry, 54(3), 607-616. https://doi.org/10.1021/jf052334j

Zhang, Y., Dai, X., Jia, D., Li, H., Wang, Y., Li, C., ... He, M. (2016). Effects of plant density on grain yield, protein size distribution, and breadmaking quality of winter wheat grown under two nitrogen fertilisation rates. European Journal of Agronomy, 73, 1-10. https://doi. org/10.1016/j.eja.2015.11.015

Zhang, P., Ma, G., Wang, C., Lu, H., Li, S., Xie, Y., ... Guo, T. (2017). Effect of irrigation and nitrogen application on grain amino acid composition and protein quality in winter wheat. PLoS One, 12(6), e0178494. https://doi.org/10.1371/journal.pone.0178494

Zhu, Y., Taylor, C., Sommer, K., Wilkinson, K., \& Wirthensohn, M. (2014). Effect of deficit irrigation on almond kernel. Acta Horticulturae, 1028, 221-223.

Zhu, Y., Taylor, C., Sommer, K., Wilkinson, K., \& Wirthensohn, M. (2015). Influence of deficit irrigation strategies on fatty acid and tocopherol concentration of almond (Prunus dulcis). Food Chemistry, 173, 821826. https://doi.org/10.1016/j.foodchem.2014.10.108

How to cite this article: Aires A, Morais MC, Barreales D, et al. Variation of almond yield, biometry, $\alpha$-tocopherol levels, and antioxidant properties with nitrogen fertilization. J Food Biochem. 2018;42:e12685. https://doi.org/10.1111/ $\underline{\text { jfbc. } 12685}$ 